\title{
Monitoring and analysis of seismic data during the 2018 sunda strait tsunami
}

\author{
Wahyu Kurniawan $^{1,2^{*}}$, Daryono ${ }^{1,2}$, IDK Kerta ${ }^{1}$, Bayu Pranata $^{2,3}$, and Tri Winugroho ${ }^{1}$ \\ ${ }^{1}$ Disaster Management Study Program, National Security Faculty, Republic of Indonesia Defense University. IPSC Sentul Area, \\ Bogor, West Java, Indonesia \\ ${ }^{2}$ Indonesian Agency for Meteorological, Climatotlogical, and Geophysics, Jakarta, Indonesia \\ ${ }^{3}$ Earth science Study Program, Institute of Technology Bandung, Indonesia
}

\begin{abstract}
The tsunami of Sunda Strait occurred on December 22, 2018, at 21:03 West Indonesia Time (zone). An eruption of Mount Anak Krakatau caused an eruption that triggered a landslide on the slopes of Mount Anak Krakatau covering an area of 64 hectares that hit the coastal area of western Banten and southern Lampung and resulted in 437 deaths, 14.059 people were injured, and 33.721 people were displaced. Before the tsunami, signal transmissions (gaps) at the Lava seismograph station installed on the body of Mount Anak Krakatau experienced broken so that Mount Anak Krakatau Observation Post could not record volcanic earthquake signals since December 22, 2018, at 21.03 West Indonesia Time (zone). Given these facts, proper monitoring and analysis were required to monitor and analyze the source of ground vibrations originating from the eruption of Mount Anak Krakatau. Therefore, this study aims to confirm the eruptive activity of Mount Anak Krakatau based on seismic monitoring and analysis sourced from the BMKG's seismic sensor network. The method the author uses is by monitoring the seismic signal recorded by the seismometer and analyzing the seismic signal using the Seiscomp3 software. By the results of monitoring and analysis of seismic data, it was found that the location of the center of the ground shaking was on Mount Anak Krakatau with a magnitude of 3.4 , and a depth of $1 \mathrm{~km}$. To anticipate similar tsunami events in the future, it is very necessary to have a tsunami early warning system originating from volcanic activity and volcanic body avalanches.
\end{abstract}

\section{Introduction}

Indonesia is located in an area prone to destructive earthquakes, because of the presence of four active world plates in Indonesian territory, namely the Eurasian plate, the Indo-Australian plate, the Pacific plate, and the Philippine sea plate [1]. Several areas on islands that are directly opposite the subduction zone between these plates, such as the western part of Sumatra Island, southern Java Island, Nusa Tenggara, northern Papua, and Sulawesi and Maluku are areas that are very prone to tsunamis. In addition, the distribution of volcanoes that extends from Aceh to North Sulawesi for approximately $7,000 \mathrm{~km}$ is signing Indonesia as a ring of fire, impacting as one of the largest number countries of active volcanoes in the world [2]. There is

a close relationship between volcanic density and the angle of subduction, the speed of oceanic plate motion, tectonic pressure behind the arc, and the slope of the heading of subduction [3].

Especially in the Sunda Strait area, there is a Megathrust subduction route and the presence of the
Anak Krakatau Volcano makes this area very prone to tsunamis, both tsunamis caused by earthquakes and caused by the eruption of volcanic.

From year 416 to 2018 , the large strength of a tectonic earthquake was occurred on August 24, 1757, in the Java Sea (northeast of the Sunda Strait) with a magnitude of 7.5, and December 16, in 1963. It occurred in Banten with a magnitude of 6.5 [4]. On the other hand, a height of tsunami up to 30 meters with a range of tsunami wave propagation of $800 \mathrm{~km}$ occurred on August 27, 1883, it was caused by the collapse of the body of Mount Krakatau, and a pyroclastic flow that fell into the sea which resulted in 36,000 deaths [5]. The fatalities amount in the eruption of Mount Krakatau, one of which is because the volcanic area is a fertile agricultural area, and the object of mass natural tourism visits so that it tends to be crowded by humans [6]. The distribution of the direction of the tsunami waves caused by the eruption of Mount Krakatau in 1883 can be seen in Fig. 1. After the paroxysmal eruption in 1883 of the Krakatau Volcanic Complex, a young volcano appeared in the caldera, namely the Anak Krakatau Volcano.

\footnotetext{
*Corresponding Author: wahyubintaro1985@gmail.com
} 
Anak Krakatau Volcano, located in the Sunda Strait, is

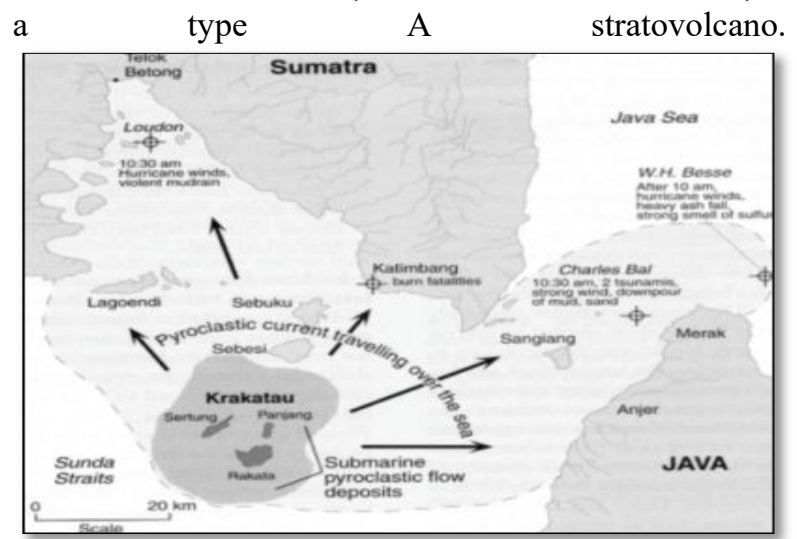

Fig. 1. Map of the distribution of the direction of the tsunami waves caused by the eruption of Mount Krakatau in 1883. [7].

Indications of the presence of an embryo of Mount Anak Krakatau have been known since the appearance of early eruption symptoms were observed from December 29, 1927, to January 5, 1928, at a geographical position of $105025^{\prime} 27^{\prime \prime}$ east and $606^{\prime} 6^{\prime \prime}$ South Latitude, as an underwater volcano at a depth of $28 \mathrm{~m}$ below sea level [8]. The body of Anak Krakatau has emerged to the sea surface since 1929. Till now Mount Anak Krakatau is in the construction phase (building its body to be big). In 2016 the eruption occurred on June 20, 2016 meanwhile the eruption occurred on February 19, 2017, in the shape of a Strombolian eruption [9].

The types and types of eruptions of Mount Anak Krakatau are phreatomagmatic, and the threat of danger can be in the form of volcanic debris that causes the tsunami.

A network of 6 seismic stations namely KRA1, KRA2, KRA3, SRTG, PULO, and LAVA stations do observations for volcanic earthquakes on Mount Anak Krakatau were monitored through the locations of the KRA1, KRA2, and KRA3 seismic stations are on Anakkrakatau Island. Meanwhile, the SRTG seismic station on Sertung Island and the PULO seismic station in the Mount Pulosari area, Pandeglang Regency, Banten. and the LAVA seismic station in the northeast of Anak Krakatau Island. The types of volcanic earthquakes recorded on Mount Anak Krakatau are eruptive earthquakes, gusts earthquakes, continuous tremors, harmonic tremors, shallow volcanic earthquakes (VB), and deep volcanic earthquakes (VA). Meanwhile, the recorded tectonic earthquakes are consist of local tectonic earthquakes and distant tectonic earthquakes [10].

On December 22, 2018, at 21.03 WIB, The LAVA Seismic Station of the Mount Anak Krakatau Observation Post did not record volcanic earthquakes. The earthquake measuring instrument installed on the body of Mount Anak Krakatau was reporting that there was an incident of loss of signal transmission from $t$. At 21:27 West Indonesia Time (Zone), the Meteorology, Climatology, and Geophysics Agency (BMKG) gave a press release stating that there had been a tsunami on the coasts of Banten and Lampung caused by landslides from the eruption of Mount Anak Krakatau. The flank collapse on the 64-hectare Anak Krakatau wall has caused a tsunami in the Sunda Strait (Tim Pengusul. 2019). This tsunami has resulted in 437 deaths, 14,059 people were injured, and 33,721 people are displaced. The result of the avalanche turned out to have changed the morphology of Anak Krakatau can be seen in Fig. 2.
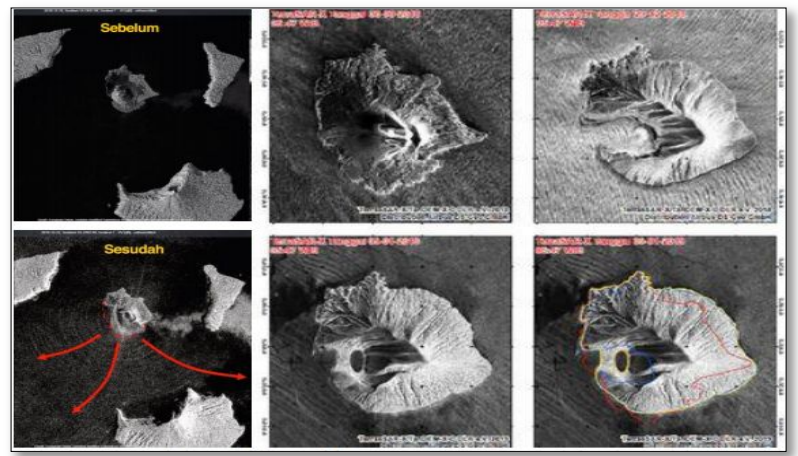

Fig. 2. Geomorphological site changes of Mount Anak Krakatau before and after the Sunda Strait tsunami.

Changes in the shape of Mount Anak Krakatau can be seen from the traces of its activities which are most likely triggered by the activity of Mount Anak Krakatau which erupts periodically and continuously, the collapse of the slopes in the western part that occurred on December 22, 2018, which resulted in waves that damaged the surrounding area, The force of the eruption had removed the peak of Mount Anak Krakatau, and Mount Anak Krakatau had begun to form again. These changes are related to the loss of mountain peaks. The upper volcanic cone of Mount Anak Krakatau disappeared due to the eruption and left a large crater wall and the highest peak of 158,635 masl at coordinates $(547224,919 ; 9325617,886)$ UTM [11]. This crater wall opens to the southwest which can be seen in Fig. 3 .

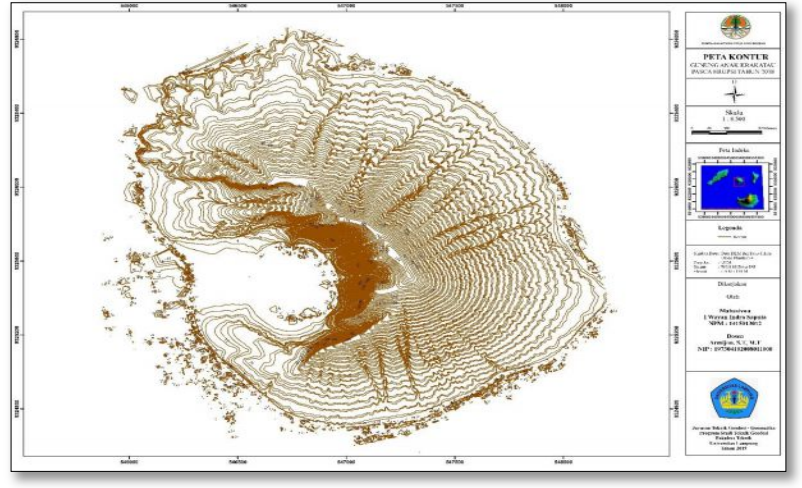

Fig. 3. Condition of Mount Anak Krakatau

The landslide may have changed the mountain passage and opened a new portion that drains magma directly into the sea surface. It is likely to trigger the meeting of hot magma with water, but over time there are also traces of seawater that stop entering the magma system so that Mount Anak Krakatau returns to normal. This kind of morphological change has always occurred on Mount Anak Krakatau throughout the history of its activities. 
The Sunda Strait area is a National Strategic Area. The Sunda Strait Strategic Area includes land, island, and sea areas located within Lampung Province, Banten Province, and other areas determined based on a development plan [12]. The development of a national strategic area of the Sunda Strait must pay attention to its geological aspects, both geological resource factors that support human sustainability to sustain life, and geological obstacles/obstacles that can cause human survival, vulnerability to human survival., when viewed from a geological point of view, the mandate is clear.

There are various facts regarding the 2018 Sunda Strait tsunami, so one way to monitor volcanic earthquake activity at the Anak Krakatau Volcano is by monitoring seismic data using a seismic sensor network belonging to the Meteorology, Climatology and Geophysics Agency (BMKG). In 2021, the Meteorology, Climatology and Geophysics Agency (BMKG) has 411 seismic network stations, it was making an alternative for monitoring volcanic earthquake activity at Anak Krakatau Volcano in the Sunda Strait and can analyze non-tectonic seismic data using Seiscomp3 software to obtain fast and accurate analysis results. The purpose of this study is to monitor and analyze seismic data during the 2018 Sunda Strait tsunami.

\section{Method}

This study uses descriptive qualitative research methods. The data obtained by the researchers were through observation, documentation, archival records, and physical devices. Data is reduced and analyzed and presented in the form of tables and pictures then conclusions are drawn. The monitoring process and anatomizing the Sunda Strait tsunami uses the Seiscomp3 software specifically monitors \& analyzes seismic data. Seiscomp3 software was originally a development of GFZ and earthquake $\mathrm{GmbH}$ that aims to detect seismic movements quickly and measure the magnitude of earthquakes that have the potential to trigger a tsunami in Indonesia [13]. SeisComP3 is a software package as a data acquisition system, data archiving system, quality control, and interactive analysis in real-time. SeisComP is designed with the simplicity of mind, not only for development and usage but also prioritizes speed in performing data processing automatically and manually (Tim Pengkaji, 2021). Seiscomp3 is related to the Indonesian Tsunami Early Warning System (InaTEWS) seismic sensor station network. Seiscomp3 software has 3 components, these are data acquisition, data processing, and data analysis which can be seen in Fig. 4 [14].

The flow of the seismic data monitoring and analysis system begins with the data acquisition process (data acquisition) obtained from all seismic stations and seismic data recorded on seismic sensors throughout Indonesia which are sent via satellite. In this acquisition component, seiscomp 3 uses the seedlink and Arclink protocols which aim to access seismic recording data (waveform) from seismic stations (remote sites) and then archive the data. At this time, Seedlink became the de-facto standard regarding the exchange of seismic data (waveform) known as SEED.

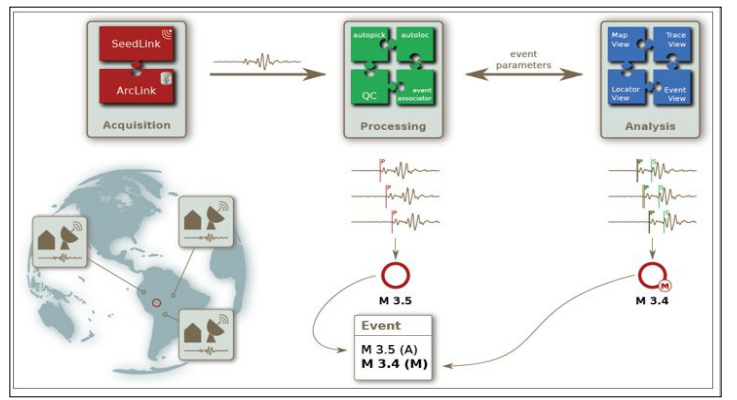

Fig. 4. Components of the Seiscomp3 software

In the data processing component, Seiscomp3 has automatic processing features that allow real-time determination of earthquake parameters such as automatic picking of $\mathrm{p}$ waves, automatic location, and automatic magnitude. automatic). This feature is also very useful as initial information on earthquake parameters before being analyzed (reviewed) manually by the operator.

In the data analysis component, Seiscomp3 provides features that allow operators to interact with the Seiscomp3 system easily (user friendly) to conduct reviews and manual analysis punctually. In this component, Seiscomp3 provides four GUIs, including:

1. Scmv (SC3 Map View), serves to display the condition and distribution of sensors in the form of a map which can be seen in Fig. 5.

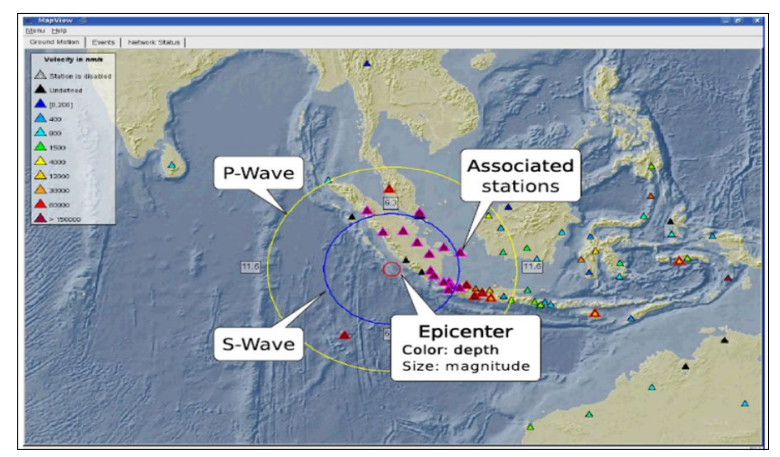

Fig. 5. GUI SCMV display.

2. Scrttv (SC3 Real-Time Trace View), serves to display seismic signals directly (real-time) which can be seen in Fig. 6 .

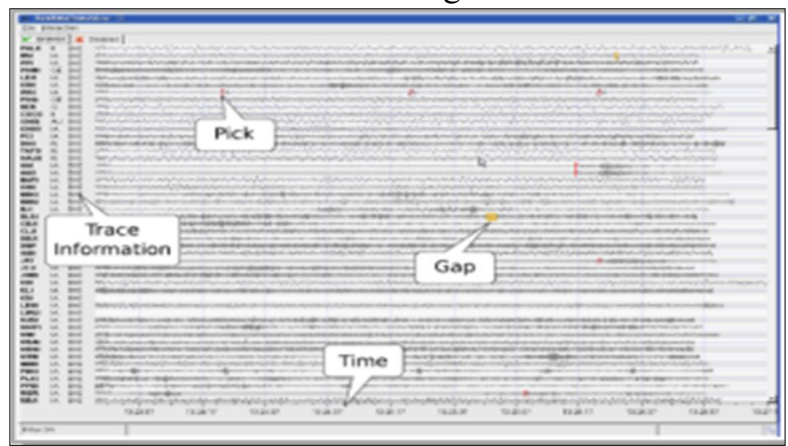

Fig. 6. GUI scrrtv display. 
3. Scolv (SC3 Origin Locator View), serves to display the processing results and the window functions to perform manual picking which can be seen in Fig.7.

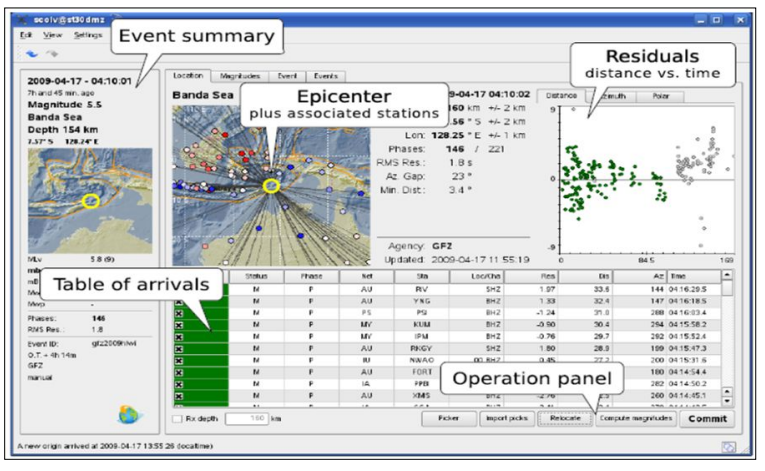

Fig. 7. GUI display of scolv.

4. Scesv (SC3 Event Summary View), serves to display the results (output) of earthquake parameters which can be seen in Fig. 8.

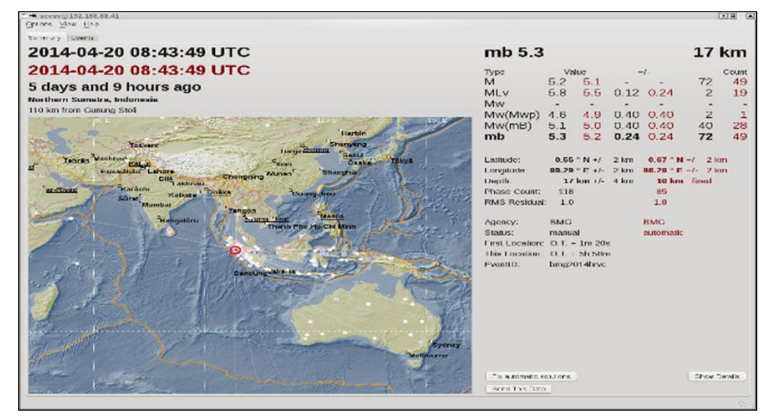

Fig. 8. GUI scesv display.

Seismic stations must obtain a minimum of 3 seismic data when manually analyzing an earthquake event. The more seismic data analyzed, the better the analysis results. Data from three seismic stations eliminates doubts because there is a meeting point of the three circles, namely the epicenter [15]. The seismic data picking process as manually, starting with picking the primary wave (p) on the vertical component and continuing to pick the secondary wave (s) on the horizontal component for each seismic station. then, the earthquake parameters are obtained such as the time of occurrence, the location of the earthquake center, namely latitude and longitude, depth, and magnitude. Constraints faced when analyzing seismic data manually are the difficulty of analyzing seismic data if there is noise (data frequency disturbance) so that it is difficult to find the best position for picking primary and secondary waves, the lack of seismic data recorded on seismic stations specifically for areas that not reachable by seismic station network.

The method that operates on the seiscomp3 software is the Geiger method. The data used in the Geiger method is the arrival time of seismic waves. The Geiger method assumes that the earth consists of a homogeneous isotropic flat layer so that the arrival time of seismic waves can be calculated due to reflection and refraction for each layer of the earth. The method used is to give the initial value of the hypocenter, then calculate the wave propagation time for each seismic station used. The basis of the calculation using the Geiger method is to find the smallest residual (r) which is influenced by the partial derivative of time to the position on each Cartesian coordinate axis $(\mathrm{x}, \mathrm{y}, \mathrm{z})$ and the difference between the observation time (tobs) and the calculation travel time (thit) which is denoted $(\Delta t)$ [16] which is shown in the following Fig 9.

$$
\mathrm{ri}=\frac{\partial \mathrm{T}}{\partial \mathrm{xi}} \Delta \mathrm{x}+\frac{\partial \mathrm{T}}{\partial \mathrm{yi}} \Delta \mathrm{y}+\frac{\partial \mathrm{T}}{\partial \mathrm{zi}} \Delta \mathrm{z}+\Delta \mathrm{t}
$$

Fig. 9. The equation of the smallest residual in the Geiger method.

\section{Result and discussion}

Seismic activity that occurred on December 22, 2018, at 20:55 WIB can be monitored by the BMKG seismic network originating from 13 seismic stations around the Sunda Strait area. Seismic stations that can record seismic activity can be seen in Table 1 .

Table 1. BMKG Seismic Stations

\begin{tabular}{|c|c|l|}
\hline No. & $\begin{array}{c}\text { Station } \\
\text { Name }\end{array}$ & \multicolumn{1}{c|}{ Station Location } \\
\hline 1 & CGJI & Cigeulis, Banten Province \\
\hline 2 & SBJI & Serang, Banten Province \\
\hline 3 & BLSI & Bandar Lampung, Lampung Province \\
\hline 4 & TNG & Tangerang, Banten Province \\
\hline 5 & TNGI & Tangerang, Banten Province \\
\hline 6 & SKJI & Sukabumi, West Java province \\
\hline 7 & LWLI & Liwa, Lampung province \\
\hline 8 & CNJI & Cacaban, West Java province \\
\hline 9 & MDSI & Muara Dua, South Sumatera Province \\
\hline 10 & LEM & Lembang, West Java province \\
\hline 11 & BBJI & Bungbulang Garut, West Java province \\
\hline 12 & JCJI & Jatiwangi, West Java province \\
\hline 13 & PMBI & Palembang, South Sumatera Province \\
\hline
\end{tabular}

Seismic data originating from 13 BMKG seismic stations were then analyzed using Seiscomp3 software by selecting the primary wave ( $\mathrm{p}$ wave) and secondary wave (s wave) correctly on each signal for each seismic station by first using a data filter of $0.4 \mathrm{~Hz}$ to $1 \mathrm{~Hz}$ which aims to make the seismic data visible. For more details, see Fig. 10.

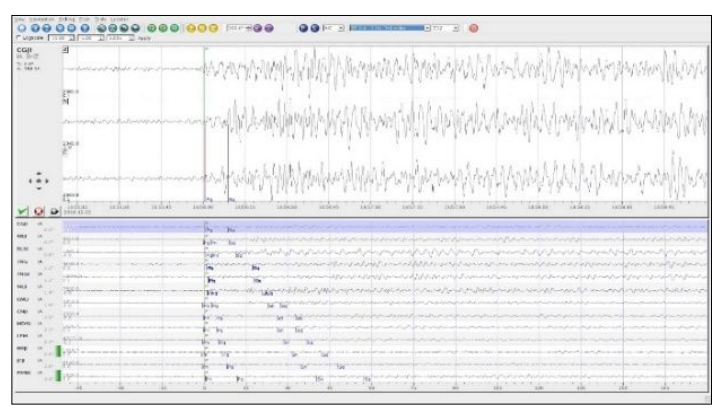

Fig. 10. Non-tectonic seismic wave recording 
After selecting and analyzing the primary waves ( $p$ waves) and secondary waves (s waves), the parameters obtained are that the vibration center is on Mount Anak Krakatau, with coordinates 105.46 East Longitude 6.10 South Latitude, $1 \mathrm{~km}$ depth, 3.4 MLv magnitude. The MLv magnitude was chosen because this event is seismic data in a local range and the seismic data is analyzed only on the vertical component ( $Z$ component). The residual rms value obtained is 0.5 . The residual $\mathrm{rms}$ value of 0.5 obtained during manual analysis is still at the fair threshold value, which does not exceed 1 (one). The rms value only depends on the velocity model used in the analysis software that determines the location of the earthquake, the quality of the determination of the arrival time of the wave, and the procedure used [17]. The results of the analysis using the Seiscomp3 software can be seen in Figs 11 and 12.

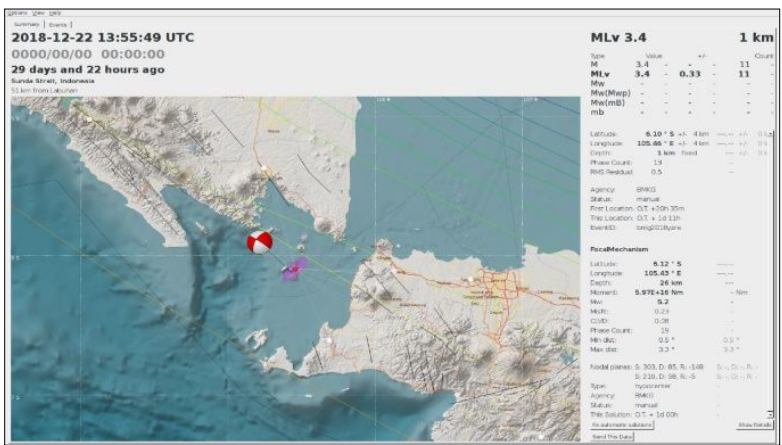

Fig. 11. Results of non-tectonic seismic data analysis using Seiscomp3

In Fig. 11 above can be seen that the position of the vibration center is right on Mount Anak Krakatau, has a vibration depth of only $1 \mathrm{~km}$ and the focal mechanism obtained is horizontal (strike-slip). Therefore, the focal mechanism can be summarized that the seismic records recorded by $13 \mathrm{BMKG}$ seismic stations are non-tectonic seismic caused by the volcanic activity of Mount Anak Krakatau.

In Fig. 12 above can be seen the position of the vibration center is right on Mount Anak Krakatau, which is symbolized by a red circle, and the position of the BMKG seismic stations which record non-tectonic seismic records symbolized by a green triangle.

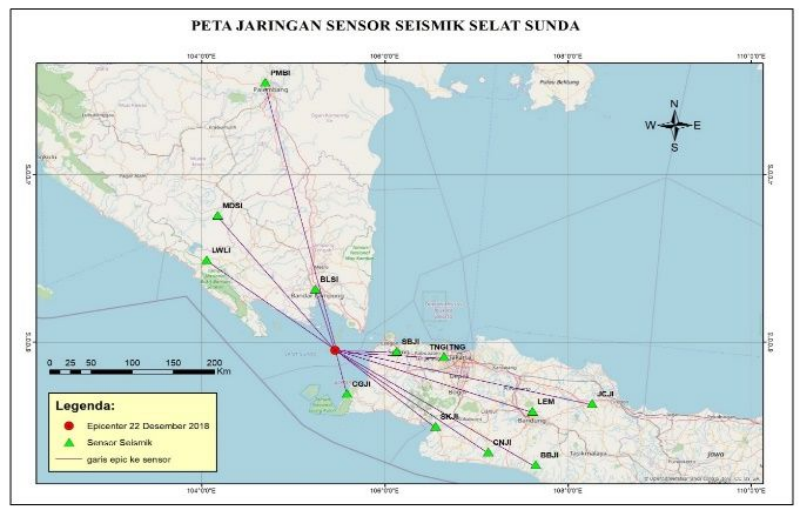

Fig. 12. Center for non-tectonic seismic vibrations from $\mathrm{BMKG}$ seismic network monitoring
The success of BMKG seismic stations in recording non-tectonic seismic activity is used as a way to quickly and accurately detect non-tectonic seismic activity on Mount Anak Krakatau.

The tsunami in the coastal areas of Banten and Lampung occurred after a vibration originating in Mount Anak Krakatau caused an avalanche of the body of Mount Anak Krakatau which then avalanche material fell into the sea, and has resulted in 437 deaths, 14,059 people were injured, and 33,721 people have been displaced. Based on the experience of the Sunda Strait tsunami, the Banten Provincial Government and the Lampung Provincial Government must increase their efforts to mitigate the tsunami structurally and nonstructurally to increase public understanding of tsunamis to reduce the risk of a tsunami disaster.

By strength of a vibration that only has a magnitude of 3.4, the tsunami early warning system in the Indonesia Tsunami Early Warning System (InaTEWS) cannot model tsunamis in the Sunda Strait region because it is only designed to model tsunamis caused by tectonic earthquakes with large strength with a wide area coverage. wider. Therefore, a tsunami early warning system is needed that originates from the activities of the Anak Krakatau Volcano, and as a result of the avalanche of the body of the Anak Krakatau Volcano and from other tsunami generating sources.

\section{Conclusion}

The activity of Non-tectonic seismic is originating from the eruption of Mount Anak Krakatau can be monitored by the BMKG seismic sensor station network, and the non-tectonic seismic data can be analyzed using the Seiscomp3 software. The output of the analysis found that the center of the vibration was on Mount Anak Krakatau, with coordinates 105.46 East Longitude 6.10 South Latitude, and a depth of $1 \mathrm{~km}$, and had strength equivalent to the power of a tectonic earthquake with a magnitude of 3.4. For anticipating similar tsunami events in the future, an early warning system for tsunamis originating from volcanic activity and volcanic avalanches was required urgently, one of which is to increase the existing network of non-tectonic seismic stations.

\section{References}

1. S. Rohadi, Study of seismotectonics as an indicator of potential earthquakes in indonesian region $j$. Meteorol. And Geophysics, 10, 111-20 (2009)

2. Fawzy N A B H M and I. Massinai, Identification of mount merapi volcanic earthquake focus mechanism (2018)

3. D. Shimozuru and N. K, Volcanic spacing and subduction, Arc Volcanics: Physics and Tectonics, (Tokyo: Terra Scientific Publishing, 1983)

4 Tsunami catalog year, 416-2018 (Jakarta: BMKG)

5. J. Beget, Volcanic tsunamis (Academic Press, 2000) 
6. I. Pratomo, Classification of Indonesian active volcanoes, case studies of several volcanic eruptions in the history of J. Geol. Indonesia, I, 209-27 (2006)

7. Valentine, G.A, and R. Fisher, Pyroclastic surges and blasts (Academic Press, 2000)

8. C. E. Stehn, The Geology and Volcanism of the Krakatau group (Batavia, 1929)

9. PVMBG, Latest Developments on Mount Anak Krakatau's Activity, PVMBG: The height of the mountain is only 110 meters (2018)

10. Preparation Team for the 2019 Geological Agency Geological Dynamics of the Sunda Strait in Sustainable Development (Bandung: Geological Agency of the Ministry of Energy and Mineral Resources)

11. A. Armijon, E. Rahmadi, I. Susanti and F. Murdapa, Study on the Update of the Lampung Bay Coastal Tsunami Immersion Model Due to the Effect (2019)
12. Anon, Presidential Decree No.86 concerning the Development of Strategic Areas and Infrastructure of the Sunda Strait (2011)

13 J. Clinton, Seismic Monitoring and Alert In Switzerland: Realand Near-RealTime Products Of The Swiss National Seismic Networks Second Eur. Conf. Earthq. Eng. Seismol (Istanbul, 2014)

14 Anon, InaTEWS, Processing System Study Report (Jakarta: BMKG Deputy for Geophysics,2020)

15 A. Wijaya, Effect of additional seismic stations (stpi, tspi, and iwpi) on the analysis of determining earthquake parameters in the case study of earthquakes in the west papua region in 2019-2020, Biolearning J. 7 10-3 (2020.)

16 K. Nishi, Hypocenter Calculation Software GAD (Geiger's method with Adaptive Damping, 2005)

17 S.Husen, E. Kissling, N. Deichmann, S. Wiemer, D. Giardini, \& M. Baer, Probabilistic earthquake location in complex three-dimensional velocity models Appl. to Switzerland, J.Geophys. Res (2003) 